JCH (Jurnal Cendekia Hukum)

Volume 6 Nomor 1, September 2020

e-ISSN: 2580-1678 dan ISSN: 2355-4657

Open Access: http://e-jurnal.stih-pm.ac.id/index.php/cendekeahukum/index

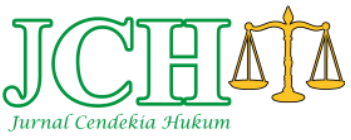

\title{
KEBIJAKAN REFORMA AGRARIA TERHADAP LAHAN PERTANIAN DI KABUPATEN TULUNGAGUNG*
}

\author{
"Siti Chadijah ${ }^{1}$, Dwi Kusumo Wardhani ${ }^{2}$, Ali Imron ${ }^{3}$ \\ Fakultas Hukum, Universitas Pamulang, \\ Jl. Surya Kencana No.1 Pamulang, Tangerang Selatan \\ e-mail: Schadijah08@gmail.com ${ }^{1}$ \\ e-mail: dkusumowardhani07@gmail.com² \\ e-mail: imron_advokat77@yahoo.co.id ${ }^{3}$
}

\begin{abstract}
The phenomenon of agricultural land use change one of which occurred in Tulungagung Regency, East Java. Agricultural land in Tulungagung Regency continues to experience shrinking, triggering fears of instability in the area's food security. Thus this research aims to answer and describe how: (1) Implementation of policies on agricultural land in Tulungagung Regency and (2) Factors that influence the implementation of agrarian reform in the Tulungagung Regency. The analysis begins dissecting the laws and regulations relating to Agrarian and Agrarian Reform Policies, among others: UUPA, Perpres No. 86 of 2018 on Agrarian Reform, and is associated with regulations related to the control and use of agricultural land, among others; Law No. 41 of 2009 concerning Protection of Sustainable Agricultural Land. Furthermore, reviewing the regulations at the Tulungagung District Land Office related to the Agrarian Reform on the Control and Use of Agricultural Land and Regional Regulations in force, then photographing how they are applied in the field so as to draw conclusions from the factors that influence the implementation of Agrarian Reform, one of which is a change use of agricultural land to become non-agricultural. The results of the study concluded that a strategic step is needed in the form of food agricultural land protection in Tulungagung Regency by regulating and immediately establishing it as a Sustainable Food Agriculture Area.
\end{abstract}

Keywords: Regulation; Agrarian reform; Agricultaral Land.

\section{Abstrak}

Fenomena alih fungsi lahan pertanian salah satunya terjadi di Kabupaten Tulungagung, Jawa Timur. Lahan pertanian di Kabupaten Tulungagung terus mengalami penyusutan, sehingga memicu kekhawatiran akan terjadinya instabilitas ketahanan pangan daerah tersebutPenelitian ini bertujuan untuk menjawab dan mendeskripsikan bagaimana : (1) implementasi kebijakan tentang lahan pertanian di Kabupaten Tulungagung dan (2) menelaah faktor-faktor yang mempengaruhi pelaksanaan reforma agraria di wilayah Kabupaten Tulungagung. Analisis diawali membedah peraturan perundang-undangan terkait Agraria dan Kebijakan Reforma Agraria antara lain : UUPA Nomor 5 Tahun 1960, Perpres No 86 Tahun 2018 tentang Reforma Agraria, UU No 41 Tahun 2009 tentang Perlindungan Lahan Pertanian Pangan Berkelanjutan. Selanjutnya digali peraturan-peraturan di Kantor Pertanahan Kabupaten Tulungagung terkait Reforma Agraria terhadap Penguasaan dan Penggunaan lahan Pertanian dan Peraturan Daerah yang berlaku, kemudian dipotret bagaimana pelaksanaannya di lapangan sehingga dapat ditarik simpulan faktorfaktor yang mempengaruhi pelaksanaan Reforma Agraria tersebut yakni salah satunya terdapat alih fungsi lahan pertanian menjadi non-pertanian. Hasil penelitian menyimpulkan bahwa dibutuhkan langkah strategis berupa perlindungan terhadap lahan pertanian pangan di Kabupaten Tulungagung dengan melakukan penataan dan segera ditetapkan sebagai Kawasan Pertanian Pangan Berkelanjutan.

Kata Kunci: Kebijakan; Reforma Agraria; Lahan Pertanian.

\footnotetext{
* Naskah diterima: 19 Agustus 2020, direvisi: 11 September 2020, disetujui untuk terbit: 28 September 2020 Doi: $10.3376 /$ jch.v6i1.286
} 


\section{PENDAHULUAN}

Kebijakan reforma agraria sebagai bagian dari pembangunan nasional, dapat dijadikan dasar pula untuk kebijakan ekonomi nasional melalui upaya pemerataan, pengurangan kesenjangan, penanggulangan kemiskinan serta penciptaan lapangan kerja di pedesaan. Reforma agraria difungsikan dalam hal memperkuat pemilikan tanah untuk seluruh rakyat Indonesia, terutama masyarakat yang tak punya tanah, baik yang tinggal di pedesaan, pinggir-pinggir hutan, pesisir-pesisir pantai, pulau-pulau kecil, maupun di lereng-lereng pegunungan.

Reforma Agraria diharapkan membawa pada peningkatan keamanan pangan, pendapatan dan kesejahteraan keluarga dari kelompokkelompok masyarakat desa yang termarjinalisasi, termasuk perempuan dan masyarakat adat, legalisasi dan perlindungan hak-hak tanah ikut memperkuat pertanian lokal dan keragaman budaya. (Martua S, Heru P, dan Dyah I.M, 2010)

Keberadaan lahan pertanian pangan sebagai bagian dari lahan fungsi budidaya sangat penting dalam menyokong kedaulatan pangan baik untuk memenuhi kebutuhan wilayahnya maupun untuk dijual ke luar wilayahnya. Namun demikian, permasalahan yang paling mendasar dari sektor pertanian ini adalah semakin menyusutnya lahan pertanian akibat alih fungsi lahan. Lahan merupakan faktor utama dalam pengembangan pertanian.

Atas dasar hal tersebut, pada tahun 2009 Pemerintah bersama-sama dengan DPR mengesahkan lahirnya UndangUndang No.41 Tahun 2009 tentang Lahan Pertanian Pangan Berkelanjutan (LP2B).

Undang-undang ini diharapkan dapat menahan laju konversi lahan sawah sehingga dapat menopang ketahanan komoditas pangan di Indonesia. Di dalam kaitan antara UU No 5 tahun 1960 tentang Pokok-Pokok Agraria (UUPA) dengan UU No. 41 Tahun 2009 tentang LP2B (UU LP2B) adalah saling melengkapi dimana Reforma Agraria menetapkan luasan kepemilikan dan penguasaan lahan, sedangkan UU LP2B lebih kepada upaya mempertahankan status luasan lahan pertanian produktif agar tidak terjadi konversi lahan ke non-pertanian, meskipun lahan tersebut dapat dialihkan status kepemilikan dan kepenguasaannya tetapi fungsinya tetap sebagai lahan pertanian.

Kabupaten Tulungagung menjadi salah satu dari Kabupaten di Provinsi Jawa Timur yang telah memiliki Peraturan Daerah terkait perlindungan lahan pertanian, yakni dengan dikeluarkannya Perda Nomor 18 Tahun 2012 tentang Perlindungan Lahan Pertanian Pangan Berkelanjutan.

Pada Kabupaten tulungagung sektor pertanian merupakan salah satu sektor penting dalam perekonomian, seharusnya dikembangkan dengan tetap 
mempertahankan luasan lahan pertanian berkelanjutan dan tidak ada alih fungsi. Menurut keterangan Kabid Sanitasi dan Prasarana Dinas Pertanian Kabupaten Tulungagung, "Hampir setiap tahun lahan pertanian yang beralih fungsi menjadi permukiman ataupun bangunan pabrik mencapai 5-10 hektare" (https://jatim.antaranews.com/berita/7478 5/lahan-pertanian-di-tulungagung-terusmenyusut, akses 3 Agustus 2019), sehingga Pemerintah Daerah Kabupaten Tulungagung perlu membatasi lahanlahan pertanian dan pangan agar tidak terjadi penyusutan lahan-lahan tersebut sebagai akibat adanya konversi lahan pertanian menjadi non-pertanian.

Rumusan masalah yang hendak penulis suguhkan pada penulisan jurnal ilmiah ini adalah: Bagaimana Implementasi kebijakan Reforma Agraria Terhadap Lahan Pertanian di Kabupaten Tulungagung, Jawa Timur? Apa saja faktor pendukung dan penghambat dalam pelaksanaan reforma agraria pada lahan pertanian di Kabupaten Tulungagung, Jawa Timur?

\section{METODE PENELITIAN}

Penelitian ini bertujuan mengembangkan ilmu pengetahuan untuk mengungkapkan kebenaran-kebenaran secara sistematis, analisis dan konstruktif terhadap data yang telah dihimpun dan diolah dengan menggambarkan makna tindakan-tindakan sosial dan simbolsimbol yang terjadi di dalam pelaksanaan reforma agraria khususnya terhadap penguasaan dan penggunaan lahan pertanian di Kabupaten Tulungagung, penelitian ini secara garis besar dapat dikelompokkan ke dalam ranah pendekatan socio-legal research.

Data dalam penelitian ini diperoleh dengan melakukan wawancara dan studi dokumen. Wawancara yang dimaksud dalam penelitian ini yaitu wawancara bebas terpimpin, yaitu dengan mempersiapkan terlebih dahulu daftar pertanyaan sebagai pedoman, tetapi secara teknis dimungkinkan adanya variasi pertanyaan yang akan disesuikan dengan situasi dan kondisi pada saat wawancara, sehingga proses tanya jawab dapat berjalan lancar dan narasumber dapat lebih mempersiapkan jawabannya. Adapun narasumber yang diwawancarai adalah Kepala Seksi Pengolahan Lahan dan Air Dinas Pertanian Kabupaten Tulungagung dan Kepala Seksi Penatagunaan Tanah Kantor Pertanahan Kabupaten Tulungagung. Studi dokumen dimaksudkan untuk mencari landasan teoretis dari permasalahan penelitian yang bertujuan untuk menunjukkan jalan pemecahan penelitian (Bambang Sunggono, 2006), yang bersumber pada peraturan perundang-undangan terkait, buku pustaka, dan jurnal ilmiah penunjang penelitian ini.

\section{HASIL DAN PEMBAHASAN}

\section{Konsep Reforma Agraria}

Istilah agraria berasal dari kata akker (bahasa Belanda), agros (bahasa Yunani) yang berarti tanah pertanian, agger ( bahasa Latin) yang berarti tanah atau sebidang tanah, agrarian (bahasa Latin) yang berarti tanah untuk pertanian 
Siti Chadijah, Dwi Kusumo Wardhani, Ali Imron: Kebijakan Reforma Agraria...

(Santoso. 2012). Kata reform merujuk pada perombakan, mengubah dan menyusun/membentuk kembali sesuatu menuju perbaikan.

Istilah lain dari Reforma Agraria adalah Pembaharuan agraria yang merupakan proses restrukturisasi (penataan ulang susunan) kepemilikan, penguasaan, dan penggunaan sumbersumber agrarian (khususnya tanah). (Waskito, dkk. 2007)

Selanjutnya terkait pengertian reforma agraria menurut Perpres Nomor 86 Tahun 2018 tentang Reforma Agraria adalah penataan kembali struktur penguasaan, pemilikan, penggunaan, dan pemanfaatan tanah yang lebih berkeadilan melalui Penataan Aset dan disertai dengan Penataan Akses untuk kemakmuran rakyat Indonesia.

Berdasarkan hal tersebut tujuan dari adanya program Reforma Agraria untuk mengubah susunan masyarakat warisan stelsel feodalisme dan kolonialisme menjadi susunan masyarakat yang adil dan merata (Gunawan Wiradi, 2000).

Istilah Pembaruan Agraria baru diperkenalkan di tahun 2001, yakni sejak lahirnya Tap MPR Nomor IX/MPR/2001 tentang Pembaruan Agraria dan pengelolaan Sumber Daya Alam, yang berarti bahwa istilah Reforma Agraria (Agrarian Reform) lebih dulu dikenal dalam wacana ilmiah dibandingkan istilah Pembaruan Agraria. (Bernhard Limbong, 2012)

Pemerintah melaksanakan agenda Reforma Agraria dengan mengeluarkan
Peraturan Presiden Nomor 86 Tahun 2018 tentang Reforma Agraria (Perpres Reforma Agraria). Perpres tersebut menjadi komitmen pemerintah untuk melakukan penataan aset dan akses agraria yang telah diamanatkan dalam TAP MPR NO. IX/MPR/2001 dan Undang-Undang Pokok Agraria. (Sulasi Rongiyati, 2018)

Pada hakikatnya reforma agraria mencakup tiga konsep berikut:

1. Konsep landreform, yakni penataan kembali struktur penguasaan kepemilikan tanah yang lebih adil

2. Konsep acces reform, yakni berkaitan dengan penataan penggunaan atau pemanfaatan tanah yang lebih produktif disertai penataan dukungan sarana dan prasarana yang memungkinkan petani memperoleh akses ke sumber ekonomi di wilayah pedesaan. Akses tersebut antara lain akses sarana dan prasarana pertanian, pengairan, jalan, usaha tani, pemasaran produksi, koperasi usaha tani, dan perbankan (kredit usaha rakyat)

3. Konsep policy atau regulation reform, yakni berkenaan dengan pengaturan kebijakan dan hukum yang berpihak pada rakyat banyak. (Sulasi Rongiyati, 2018)

2. Implementasi Kebijakan Reforma Agraria terhadap Lahan Pertanian di Kabupaten Tulungagung, Jawa Timur

Pada era globalisasi saat ini, diketahui bahwa jumlah lahan pertanian, 
khususnya yang digunakan untuk memproduksi pangan tidak tumbuh sebanding dengan pertumbuhan penduduk, atau dengan kata lain pertumbuhan ketersediaan lahan pertanian rakyat menjadi berkurang. Hal ini disebabkan tingginya angka pengalihfungsian lahan pertanian untuk tujuan penggunaan lain.

Alih fungsi lahan dapat mempersulit Pemerintah, baik pemerintah pusat maupun daerah untuk menciptakan kemandirian, ketahanan, dan kedaulatan pangan, karena sektor pangan merupakan kebutuhan pokok setiap masyarakat sehingga mutlak harus dipenuhi. Akan tetapi, akibat terjadinya alih fungsi lahan pertanian menjadi non pertanian menyebabkan negara harus memberikan kebijakan agar mampu melindungi lahan pertanian. Hal ini dimaksudkan agar ketersediaan lahan pertanian pangan dapat terus dipertahankan agar kebutuhan masyarakat Indonesia terkait hak atas pangan dapat terpenuhi dengan baik. (Ayu dan Heriawanto, 2018)

Pada Kabupaten tulungagung sektor pertanian merupakan salah satu sektor penting dalam perekonomian, seharusnya dikembangkan dengan tetap mempertahankan luasan lahan pertanian berkelanjutan dan tidak ada alih fungsi.

Menurut keterangan Kepala Seksi Pengelolaan Lahan dan Irigasi Dinas Pertanian Kabupaten Tulungagung, "Hampir setiap tahun lahan pertanian yang beralih fungsi menjadi non pertanian misalnya untuk permukiman ataupun industri”, dalam keterangannya ia menunjukkan hasil survey lapangan dan digitasi penggunaan lahan eksisting tahun 2019 ditemukan bahwa lahan pertanian di Kabupaten Tulungagung sebagaimana Keputusan Menteri Agraria dan Tata Ruang / Kepala Badan Pertanahan Nasional Nomor 399 Tahun 2018, telah beralih fungsi menjadi bukan pertanian yaitu seluas 1.805,43 Ha (Kepala Seksi Pengelolaan Lahan dan Irigasi Dinas Pertanian Kabupaten Tulungagung, wawancara, 21 Februari 2020). Sehingga pemerintah perlu membatasi lahan-lahan pertanian dan pangan agar tidak terjadi penyusutan lahan-lahan tersebut sebagai akibat adanya konversi lahan pertanian menjadi non-pertanian.

Menjadi tugas negara untuk memajukan kehidupan rakyat secara umum dan meningkatkan taraf penghidupannya. Hak menguasai Negara ini termaktub dalam Pasal 33 Undangundang Dasar Negara Republik Indonesia 1945 (UUD 1945) ayat (2) mangatur bahwa "Cabang-cabang produksi yang penting bagi Negara dan yang menguasai hajat hidup orang banyak dikuasai oleh Negara" dan Ayat (3) yakni: "Bumi, air dan kekayaan alam yang terkandung didalamnya dikuasai oleh Negara dan dipergunakan untuk sebesar-besarnya kemakmuran rakyat".

Pengaturan terkait hak menguasai negara yang dilakukan oleh Pemerintah Republik Indonesia diatur pada Pasal 2 Ayat (2) Undang-undang Nomor 5 Tahun 1961 Tentang Peraturan Dasar Pokokpokok Agraria (selanjutnya disingkat UUPA), yaitu sebagai berikut: 
Siti Chadijah, Dwi Kusumo Wardhani, Ali Imron: Kebijakan Reforma Agraria...

a. Mengatur dan menyelenggarakan peruntukan, penggunaan, persediaan dan pemeliharaan bumi, air, dan ruang angkasa tersebut;

b. Menentukan dan mengatur hubunganhubungan hukum antara orang-orang dengan bumi, air, dan ruang angkasa;

c. Menentukan dan mengatur hubunganhubungan hukum antara orang-orang dan perbuatan hukum yang mengenai bumi, air, dan ruang angkasa.

Usaha pemerintah baik dalam memenuhi kebutuhan pangan penduduknya, menghadapi tantangan berat dan karena akibat fenomena alih fungsi lahan pertanian untuk tujuan penggunaan lain. Ketersediaan lahan pertanian merupakan syarat keberlanjutan sector pertanian dalam mewujudkan ketahanan dan kedaulatan pangan.

Salah satu langkah strategis perlindungan terhadap lahan pertanian pangan di Kabupaten Tulungaung adalah penataan atau pengaturan untuk ditetapkan sebagai Kawasan Pertanian Pangan Berkelanjutan (KP2B). Dengan demikian perlu dilakukan penyusunan kajian KP2B yang mempunyai tujuan sebagai berikut :

a) Memberikan arahan perencanaan, pengendalian, pemanfaatan Kawasan/Lahan Pertanian Pangan Berkelanjutan.

b) Mewujudkan Kawasan/Lahan Pertanian Pangan Berkelanjutan dengan mempertahankan luas lokasi lahan pertanian pangan yang telah ditetapkan dalam rangka menjamin pasokan pangan dan mendukung ketahanan pangan di Kabupaten Tulungagung.

Berdasarkan hasil data analisa dari tim teknis kajian Rencana Lahan Pertanian Pangan Berkelanjutan, diketahui dan telah terpetakan bahwa seluas 140.01 Ha di lokasi lahan pertanian di Kabupaten Tulungagung sebagaimana Keputusan Menteri Agraria dan Tata Ruang/ Kepala badan Pertanahan Nasioanal Nomor 399 Tahun 2018 adalah lahan/tanah yang merupakan aset Pemerintah kabupaten Tulungagung tersebar di Kecamatan Rejotangan, Karangrejo, Kauman, Ngunut, Kedungwaru, Pakel, Ngantru, Sumbergempol, Gondang, Sendang, Pagerwojo, Tulungagung dan Boyolangu. Dengan mempertimbangkan Peraturan Menteri Pertanian Nomor 07/Permentan/OT.140/2/2012 yang mengatur bahwa luas hamparan Lahan Pertanian Pangan Berkelanjutan pada satu kawasan minimal adalah $5 \mathrm{Ha}$ dan verifikasi luas pertanian pangan yang berpotensi untuk bisa dilakukan tindakan perlindungan seluas 18.250,36 $\mathrm{Ha}$ dan juga kriteria Lahan Pertanian Pangan Berkelanjutan sebagaimana dalam Undang-Undang Nomor 41 tahun 2009, maka dapat disimpulkan bahwa jumlah lahan pertanian di Kabupaten Tulungagung :

a. Lahan Pertanian Pangan Berkelanjutan (LP2B) adalah seluas kurang lebih : 16.350,34 Ha

b. Lahan Cadangan Pertanian Pangan Berkelanjutan (LP2CB), adalah seluas kurang lebih : 4.782,46 Ha 
c. Kawasan Pertanian Pangan

Berkelanjjutan (KP2B) adalah seluas kurang lebih : 21.132,79 Ha.

Hasil kajian rencana Lahan Peranian pangan Berkelanjutan (LP2B) Kabupaten Tulungagung selanjutnya menjadi pertimbangan dan diintegrasikan ke dalam Rencana Tata Ruang Wilayah Kabupaten Tulungagung dalam penetapan Kawasan Pertanian Pangan Berkelanjutan (KP2B) dan rencana detail tata Ruang Kabupaten dalam penetapan Lahan Pertanian Pangan Berkelanjutan (LP2B) serta Lahan Cadangan Pertanian Pangan Berkelanjutan (LP2CB), sesuai ketentuan peraturan perundang-undangan yang berlaku.

\section{Faktor Pendukung dan Penghambat Pelaksanaan Reforma Agraria Terhadap Lahan $\begin{array}{lll}\begin{array}{l}\text { Pertanian di Kabupaten } \\ \text { Tulungagung }\end{array} & \end{array}$}

Reforma agraria adalah sebuah agenda besar yang dalam pelaksanaanya membutuhkan perencanaan yang tepat dan cermat guna memastikan tercapainya target dan tujuan yang telah ditetapkan. Secara garis besar, penyelenggaraan reforma agraria meliputi empat lingkup kegiatan utama yaitu penetapan objek; penetapan subjek; mekanisme dan delivery system reforma agraria; serta access reform. (Muhammad Ilham Arisaputra, 2015)

Berikut adalah beberapa faktor pendukung dalam pelaksanaan reforma agraria pada lahan pertanian di Kabupaten Tulungagung:
1. Dari segi regulasi, sebagai penguat UUPA dan Perpres No 86 Tahun 2018 tentang Reforma Agraria, yaitu dengan dikeluarkannya Peraturan Daerah Kabupaten Tulungagung Nomor 4 Tahun 2016 tentang Perlindungan dan Pemberdayaan Petani, khususnya pada pasal 5 ayat (2) mengenai stategi perlindungan petani, antara lain dilakukan melalui peningkatan sarana dan prasarana produksi pertanian; penghapusan praktik ekonomi biaya tinggi; dibuatnya asuransi pertanian; dan penggantian rugi jika gagal panen akibat kejadian luar biasa yang disesuaikan dengan kemampuan keuangan daerah;

2. Peraturan Daerah Kabupaten Tulungagung Nomor 20 Tahun 2017 tentang Perubahan atas Peraturan Daerah Nomor 18 Tahun 2012 tentang Perlindungan Lahan Pertanian Pangan Berkelanjutan, khususnya pada pasal 4a pada pokoknya mengatur pengembangan sistem informasi spatial untuk lahan potensi sawah irigasi dan non irigasi; percepatan pelaksanaan identifikasi LP2B; penetapan lahan pertanian pangan berkelanjutan pada rencana tata ruang;penghentian perpanjangan ijin pemanfaatan ruang di lahan peruntukan pertanian; pengembangan pelatihan sektor pertanian; dan pencegahan dan penindakan terhadap adanya tindakan pelanggaran.

3. Dikeluarkannnya pula Keputusan Bupati Tulungagung Nomor 188.45/786/013/2019 tentang 
Siti Chadijah, Dwi Kusumo Wardhani, Ali Imron: Kebijakan Reforma Agraria...

Pembentukan Tim Koordinasi

Konsolidasi Tanah Kabupaten

Tulungagung. Dalam Keputusan

Bupati tersebut dibentuk tim koordinasi tanah Kabupaten

Tulungagung, bertindak sebagai pengarah adalah Bupati

Tulungagung, Ketua oleh Sekeretarus

Daerah Kabupaten Tulungaggung, Wakil Ketua oleh Kepala Pertanahan Kabupaten Tulungagung, Sekretaris merangkap anggota adalah Kepala Seksi Penataan Pertanahan Kabupaten Tulungagung, dan lima orang anggota yaitu Kepala Badan Perencanaan Pembangunan Daerah Kabupaten Tulungagung, Kepala Dinas Pertanian Kabupaten Tulungagung, Kepala Dinas Pekerjaan Umum dan Penataan Ruang Kabupaten Tulungagung, Kepala Bagian Hukum Sekretaruat Daerah Kabupaten Tulungagung, dan Kepala Dinas Perumahan, Kawasan Permukiman, dan Sumber Daya Air Kabupaten Tulungagung (Lampiran Keputusan Bupati Tulungagung Nomor 188.45/786/013/2019 tanggal 22 November 2019).

4. Kepala Dinas Pertanian Kabupaten Tulungagung beserta jajarannya telah menyiapkan data Lahan Pertanian Pangan. Adapun data LP2B Kabupaten Tulungagung yang merupakan milik perorangan (petani) berjumlah kurang lebih 26151,89 ha. Data tersebut juga menjadi dasar untuk melakukan revisi Rencana Tata Ruang Wilayah (RTRW) Provinsi Jawa Timur.
Dari faktor penunjang yang telah disebutkan di atas, Pemerintah Daerah Kabupaten Tulungagung berupaya memaksimalkan lahan pertanian yang telah ada sebagai objek reforma agraria khususnya di bidang pertanian, karena memang tidak diadakan penambahan lahan pertanian, akan tetapi fokusnya ada pada optimalisasi hasil pertanian dan dapat memberikan akses pada penerima manfaat sebagi subjek dari reforma agraria (Kepala Seksi Pengolahan Lahan dan Air Kabupaten Tulungagung, wawancara, 27 April 2020).

Ada faktor pendukung, adapula faktor penghambat. Satu dekade lebih belakangan, Indonesia disuguhkan dengan keragu-raguan tentang reforma agraria, baik itu secara pemahaman maupun pelaksanaannya. Sementara berbagai kebijakan anti reforma agraria terus berjalan, sehingga konflik-konflik agraria sampai saat ini masih terus tejadi di berbagai sektor. (Tri Chandra Aprianto, 2014)

Pelaksanaan reforma agraria di bidang pertanian Kabupaten Tulungagung juga memiliki beberapa hambatan dan tentan terjadi konflik agraria khususnya pada sektor pertanian, beberapa diantaranya adalah:

1. Kurangnya koordinasi dan komunikasi Pemerintah Daerah setempat dengan Kantor Pertanahan Kabupaten Tulungagung. sehingga kantor pertanahan kesulitan dalam melakukan pendataan lahan pertanian yang menjadi objek reforma agraria. Fakta empirisnya, banyak berdiri 
rumah-rumah warga di atas tanah yang peruntukannnya seharusnya untuk lahan pertanian, karena pemberian ijin pendirian perumahan masih cenderung dipermudah (Kepala Seksi Penatagunaan Tanah Kantor Pertanahan Kabupaten Tulungagung, wawancara, 29 April 2020).

2. Setelah dikeluarkannya Keputusan Bupati Tulungagung Nomor 188.45/786/013/2019 tentang Pembentukan Tim Koordinasi Konsolidasi Tanah Kabupaten Tulungagung, belum ada realisasi konsolidasi tanah dengan maksimal karena tengah terjadi persoalan internal pada pemerintah daerah setempat.

3. Informasi mengenai lahan pertanian baik objeknya, subjeknya, maupun mekanisme dan persebaran penguasaan, pemilikan, dan pemanfaatan lahannya tidak terekam dengan baik dalam komputerisasi data di Kantor Pertanahan (Komputerisasi Kegiatan Pertanahan). KKP itu sendiri bertujuan untuk menciptakan tertib adminsitrasi pertanahan, meningkatkan dan mempercepat pelayanan di bidang pertanahan, dan meningkatkan kualitas informasi pertanahan BPN, serta memudahkan pemeliharaan data pertanahan.

4. Reforma agraria di Kabupaten Tulungagung lebih difokuskan pada perluasan akses jalan. Hal ini memang tidak dapat dipersalahkan, karena akses jalan juga untuk mengakomodir kepentingan umum, akan tetapi perluasan akses jalan ini dilakukan dengan mengambil lahan sawah milik petani yang akhirnya mereka terima nasib lahannya dicabut alih-alih untuk kepentingan umum, tetapi hak-hak petani terpinggirkan.

5. Banyaknya permohanan masyarakat untuk melakukan pecah kepemilikan lahan pertanian baik sawah basah ataupun sawah kering. Atas dasar pembagian warisan, maka pemecahan tersebut dikabulkan permohonannya, dan setelahnya, fungsi sawah menjadi kabur, karena lebih banyak dibangun rumah/tempat tinggal (Hasil Wawancara dengan Kepala Seksi Penatagunaan Tanah Kantor Pertanahan Kabupaten Tulungagung).

\section{SIMPULAN}

Berdasarkan hasil analisa yang didukung dengan pemaparan pada bagian sebelumnya, Kabupaten Tulungagung telah mendukung upaya percepatan reforma agraria melalui dibuatnya berbagai kebijakan antara lain : Peraturan Daerah Kabupaten Tulungagung Nomor 20 Tahun 2017 tentang Perubahan atas Peraturan Daerah Nomor 18 Tahun 2012 tentang Perlindungan Lahan Pertanian Pangan Berkelanjutan, Keputusan Bupati Tulungagung Nomor $188.45 / 786 / 013 / 2019$ tentang Pembentukan Tim Koordinasi Konsolidasi Tanah Kabupaten Tulungagung, dan juga terdapat hasil data kajian rencana Lahan Pertanian Pangan Berkelanjutan dari Dinas Pertanian Kabupaten Tulungagung sebagai dasar 
Siti Chadijah, Dwi Kusumo Wardhani, Ali Imron: Kebijakan Reforma Agraria...

untuk melakukan revisi Rencana Tata Ruang Wilayah (RTRW) Provinsi Jawa Timur. Namun demikian dalam implementasinya ditemukan hambatan atau kendala sehingga tujuan reforma agraria belum tercapai. Permasalahan utama terletak pada masih terjadi peralihan kepemilikan sawah menjadi non sawah disebabkan keputusan petani di tengah pesatnya pengembangan kota. Fenomena ini menunjukkan bahwa kegiatan pertanian semakin sulit diandalkan sebagai kegiatan utama rumah tangga pedesaan.

Dengan demikian adanya perubahan kepemilikan maupun penguasaan lahan pertanian melalui berbagai proses yang dapat terjadi disebabkan oleh adanya transaksi seperti jual beli, pembagian waris, hibah atau transaksi lainnya sehingga seseorang berhak ataupun tidak berhak atas lahan pertanian tersebut. Hal ini memberikan pengaruh yang besar terhadap kehidupan ekonomi petani bahkan memunculkan jenis pekerjaan baru bagi yang bersangkutan.

Diperlukan peran Pemerintah Daerah Kabupaten Tulungagung agar konsistensi dan terus berkomitmen untuk mencegah alih fungsi lahan pertanian, serta jangan sampai mempunyai anggapan bahwa pertanian tidak cukup mendongkrak Pendapatan Asli Daerah (PAD) sehingga lebih tertarik dengan investor atau membangun peruntukkan lain pada lahan pertanian.

Pelaksanaan Kegiatan sosialisasi juga harus dilaksanakan, yakni mengenai peraturan perundang-undangan tentang alih fungsi lahan pertanian dan penindakan secara tegas terhadap pelanggaran, sehingga memberikan kesadaran bagi masyarakat, khususnya petani bahwa hal tersebut dapat berdampak pada stabilitas nasional terkait pengadaan pangan yang sifatnya penting. Terakhir, untuk memotivasi petani pemerintah harus terus memberikan bantuan pada kegiatan pertanian, seperti bantuan pupuk, bibit unggul, dan lainlain.

\section{UCAPAN TERIMA KASIH}

Penulis mengucapkan terima kasih kepada Kementrian Riset dan Teknologi Republik Indonesia telah memfasilitasi penelitian ini melalui dana hibah, Universitas Pamulang Khususnya Lembaga Penelitian dan Pengabdian Masyarakat (LPPM) yang membantu penulis dalam koresponden dengan narasumber. Penelitian ini didanai oleh Kementrian Riset dan Teknologi Republik Indonesia berdasarkan Surat Perjanjian Kontrak Penelitian Nomor: 0150/D5/KP/LPPM/UNPAM/IV/2020.

\section{DAFTAR PUSTAKA}

\section{Buku dan Literatur}

Arisaputra, M.I., (2015). Reforma Agraria Indonesia. Sinar Grafika. Jakarta.

Bambang Sunggono, 2006, Metode Penelitian Hukum, Jakarta: Raja Rajawali Pers.

Dinas Pertanian Kabupaten Tulungagung (2019). Hasil Data Kajian Rencana Lahan Pertanian Pangan.

Kepala Seksi Penatagunaan Tanah Kantor Pertanahan

Kabupaten 
Tulungagung. (2020). Wawancara pada tanggal 29 April 2020 pukul 10.00 WIB. Kantor Pertanahan Kabupaten Tulungagung.

Kepala Seksi Pengolahan Lahan dan Air Kabupaten Tulungagung. (2020). Wawancara pada tanggal 27 April 2020 pukul 10.00 WIB.

Limbong, B. (2012). Reforma Agraria. Margaretha Pustaka. Jakarta.

Santoso, Urip. (2012). Hukum Agraria Kajian Komprehesif. Kencana Prenada Media Grup. Surabaya.

Waskito, Arnowo. H., (2017). Pertanahan, Agraria, dan Tata Ruang, Kencana. Jakarta.

Wiradi, Gunawan. (2000). Reformasi Agraria: Perjalanan yang Belum Berakhir. INSIST Press. Yogyakarta.

\section{Jurnal}

Aprianto, T.C., (2014). Reforma Agraria: Momentum Keadilan Dan Kesejahteraan. Bhumi Jurnal Agraria dan Pertanahan, 39: 356358.

Ayu, I.K., Heriawanto, B.K., (2018). Perlindungan Hukum Terhadap Lahan Pertanian Akibat Terjadinya Alih Fungsi Lahan di Indonesia. Jurnal Ketahanan Pangan, 2(2) : 122-130.

Kantun, S. (2017). Penelitian Evaluatif Sebagai Salah Satu Model Penelitian dalam Bidang Pendidikan. Jurnal Ilmiah Ilmu Pendidikan, Ilmu Ekonomi dan Ilmu Sosial, 10 (2): 1-15.
Rongiyati, Sulasi. (2018). Reforma Agraria Melalui Perpres Nomor 86 Tahun 2018. Kajian Singkat Terhadap Isu Aktual dan Strategis. 10 (19) : 1.

Sihaloho, M., Purwandari, H., Mardiyaningsih, D.I., (2010). Reforma Agraria Dan Revitalisasi Pertanian Di Indonesia: Studi Kasus Pertanian Tanaman Pangan dan Hortikultura di Jawa Barat. Sodality: Jurnal Sosiologi Pedesaan, 4(1), 146-168.

\section{Internet}

Lahan Pertanian di Tulungagung terus menyusut.

(2011).

https://jatim.antaranews.com/berita/ 74785/lahan-pertanian-ditulungagung-terus-menyusut, diakses pada tanggal 03 Agustus 2019.

\section{Peraturan Perundang-Undangan}

Undang-Undang Nomor 5 Tahun 1960 tentang Peraturan Dasar PokokPokok Agraria.

Undang-Undang Nomor 41 Tahun 2009 tentang Perlindungan Lahan Pertanian Pangan Berkelanjutan

Peraturan Pemerintah Nomor 1 Tahun 2011 tentang Penetapan dan Alih Fungsi Lahan Pertanian

Peraturan Presiden Nomor 86 Tahun 2018 tentang Reforma Agraria.

Peraturan Daerah Nomor 20 Tahun 2017 tentang Perubahan atas Peraturan Daerah Nomor 18 Tahun 2012 tentang Perlindungan Lahan Pertanian Pangan Berkelanjutan. 
Siti Chadijah, Dwi Kusumo Wardhani, Ali Imron: Kebijakan Reforma Agraria...

Lampiran Keputusan Bupati Tulungagung

tanggal 22 November 2019.

Nomor

188.45/786/013/2019 